\title{
ENVIRONMENTAL ASSESSMENT AND TOURIST CARRYING CAPACITY FOR THE DEVELOPMENT OF GEOSITES IN THE FRAMEWORK OF GEOTOURISM, GUAYAQUIL, ECUADOR
}

\author{
PAÚL CARRIÓN-MERO ${ }^{1,2}$, FERNANDO MORANTE-CARBALLO ${ }^{1,3,4}$, \\ PAULA PALOMEQUE-ARÉVALO ${ }^{5} \&$ BORIS APOLO-MASACHE ${ }^{1,2}$ \\ ${ }^{1}$ ESPOL Polytechnic University, \\ Centro de Investigaciones y Proyectos Aplicados a las Ciencias de la Tierra (CIPAT), Ecuador \\ ${ }^{2}$ ESPOL Polytechnic University, Facultad de Ingeniería en Ciencias de la Tierra, Ecuador \\ ${ }^{3}$ ESPOL Polytechnic University, Facultad de Ciencias Naturales y Matemáticas (FCNM), Ecuador \\ ${ }^{4}$ Geo-recursos y Aplicaciones (GIGA), ESPOL Polytechnic University, Ecuador \\ ${ }^{5}$ UEES Espíritu Santo University, Ecuador
}

\begin{abstract}
The current world situation marked by the COVID-19 pandemic, plus the various specific situations in each locality, require an adequate response to promote development. One of the most recommended is the development of tourism, and precisely that it is linked to the environmental environments of nature. For this reason, geotourism offers guarantees of biosecurity, open spaces, and better conditions in the current situation. Guayaquil, a cosmopolitan city on the Ecuadorian coast, has unique characteristics for the development of geotourism. This work aims to carry out an environmental analysis, using the cause-consequence method and tourist carrying capacity in geosites for sustainable geotourism development. The methodology includes: (i) strategic geosites selection; (ii) environmental assessment of geosites and analysis of their carrying capacity for tourism; and (iii) interpretation of results and strategy development. The results reflect that Guayaquil has very significant potential given its natural geological and biological conditions. The union of geodiversity and biodiversity give the Guayaquil metropolis a special uniqueness, auguring an excellent future for geotourism development. It is vital the develop geosites with an environmental consideration that allows projecting towards sustainable development.
\end{abstract}

Keywords: geotourism, geosite, tourist carrying capacity, environmental assessment, Guayaquil.

\section{INTRODUCTION}

Megadiversity is characterized by many plants or animal species that inhabit the same geological site, providing biological richness [1]. The geodiversity and biodiversity present in the most megadiverse countries make these geographical areas highly recognized and visited by many tourists [2].

Geodiversity is recognized as the basis for ecological biodiversity [3], improving the use of natural resources and the tolerance of ecosystems to climate change [4], allowing its development as a natural [5], geological [6], mining [7] and cultural [8] heritage.

The geodiversity and biodiversity of a place are essential characteristics for the confirmation of the natural heritage [9], in which the development of human beings, their cultural traditions and the history of the sector stands out [10]. These sectors consist of a universal value that encompasses the scientific and educational perspective [11], promoting the conservation and maintenance of the natural beauty that magnifies its importance and reason for visitation [12].

The natural heritage is related to the geological heritage since it focuses on the places where the geological and landscape processes of the place are manifested, being unique characteristics that promote cultural, scientific and educational interest in the called geosites 
[13]. At the same time, there is a relationship with mining heritage, which focuses on anthropogenic activities performed on the surface of the earth or below it, called mining, which implements for tourism and educational purposes [14].

Geosites are essential as the abiotic matrix of ecotopes and an existing relationship between geomorphological and geological interest [15]. In addition, these sites drive the development of geotourism, offering scientists the opportunity to conduct research to enrich knowledge, promote conservation, and achieve sustainable development [16].

Geotourism is a new form of geographic tourism that focuses on visiting fantastic scenic and scenic places [17], [18]. This term was born as a strategy of geoconservation of the biophysical and cultural characteristics of the geosite, being an option to promote sustainable development in rural areas [5].

Geoconservation is a term used to refer to the set of actions and strategies aimed at the conservation and preservation of geological heritage [19]. This motivates the development of strategies to conserve the site's natural resources, habitats, and flora and fauna [20], [21]. These characteristics are essential for the creation of the so-called geoparks [22].

UNESCO Global Geoparks are a network of unique geographic areas of international geological importance [23], which makes use of geological heritage to improve the awareness and understanding of society through geotourism [24], [25]. In addition, these places have an ethnographic, ecological and cultural variety, having their first appearance in European countries and later joining South America, such as Ecuador [26].

Ecuador recognizes as a megadiverse country located in the southern hemisphere of the American continent [27]. It has scenic and tourist attractions that frame its geological evolution. These places stand out in the various geographical regions of continental and insular Ecuador. Its unique features include valleys, volcanoes, basins, and other geographical features that frame the geo-biodiversity it possesses. [28]. Therefore, there is an extensive natural, geological and cultural heritage within the territory that has changed over time due to geological and geomorphological processes [29]. The first geopark in Ecuador, recognized by UNESCO in 2019, is the Imbabura Global Geopark, located in the northern Andean part of Ecuador [30].

Guayaquil, also known as the pearl of the Pacific, and Ecuador's main port, is a city of international interest since it has very significant potential given its natural geological and biological conditions [31]. Moreover, the combination of the geodiversity and biodiversity of the metropolis of Guayaquil gives it a special uniqueness [32], auguring an excellent future for social, economic, cultural and geotourism development [16]. The city has heritage values that emphasize elements of geodiversity [33], [34], recognizing it as a symbol of the Ecuadorian coast.

\section{OBJECTIVES}

The problem that occurs in Guayaquil is defining by the following question: How would we recognize the environmental status and physical carrying capacity of four geosites of the city of Guayaquil for taking measures in the context of sustainable development? Therefore, the research aims to evaluate four geosite of Guayaquil city, considering environmental aspects using a cause-effect matrix. The tourism topic is also considering, calculating the carrying capacity of each of the geosites in the study area. Environmental valuation and carrying capacity are crucial to establishing strategies that lead to sustainable development. 


\section{MATERIALS AND METHODS}

The present work focuses on the application of three different phases (Fig. 1), focused on: (i) strategic geosites selection; (ii) environmental assessment of geosites and analysis of their carrying capacity for tourism; and (iii) interpretation of results and strategy development.

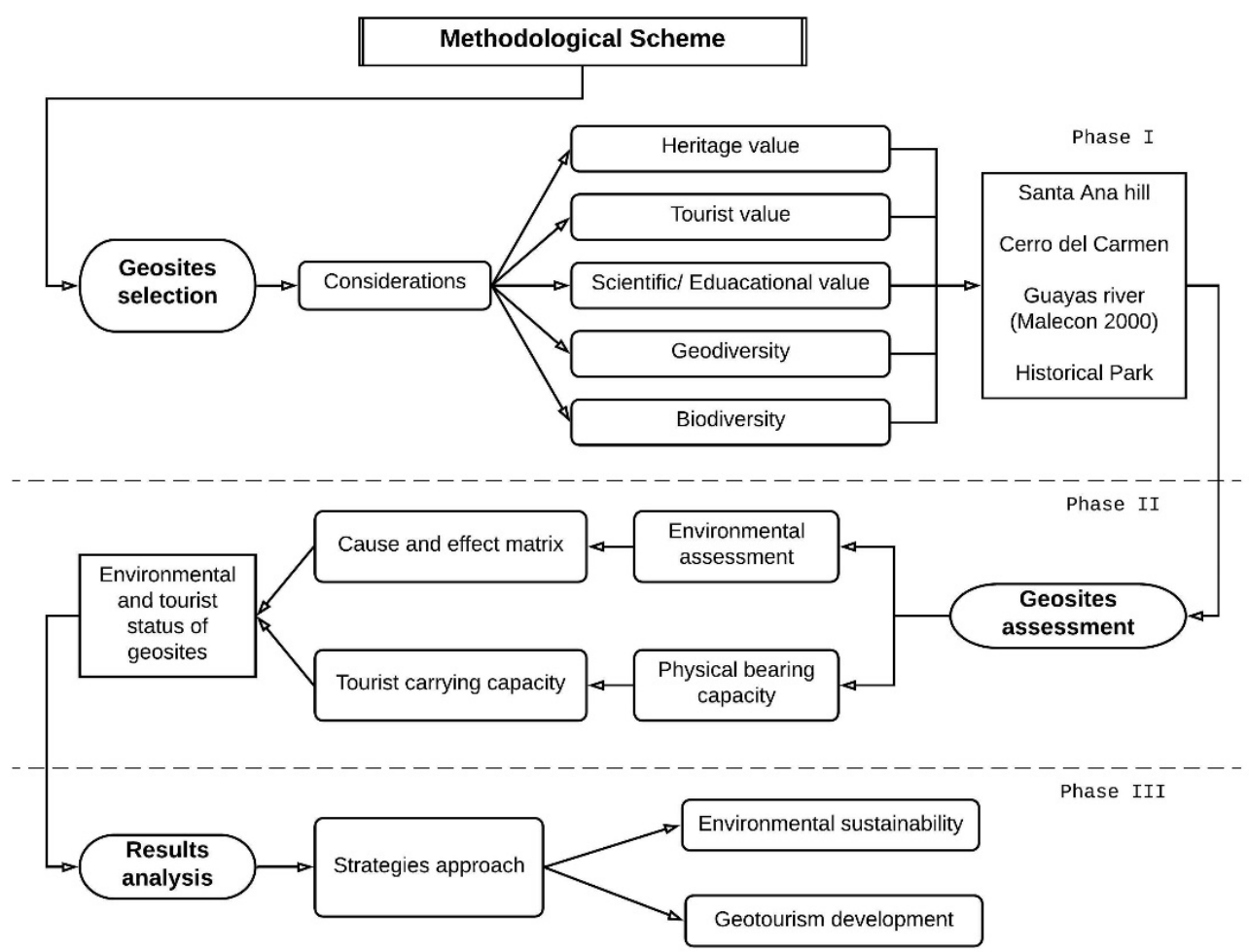

Figure 1: Diagram of the methodology and phases implemented in the development of the research work.

\subsection{Phase I: Strategic geosites selection}

From a group of geosites already valued for their geological relevance in the scientific contribution of Carrión-Mero et al. [16], four geosites representatives of the city of Guayaquil are selecting. Among which are: Cerro del Carmen, Santa Ana hill, Guayas River (Malecón 2000) and the Historical Park (Fig. 2). It should note that these places have an already established tourist preponderance in the city, and in this work, their geological value is adding for a critical, synergistic and developmental analysis.

These sites are recognizing for their high tourist, educational and recreational activity. However, these sites need an assessment of their current environmental status and the maximum capacity of tourists they can accommodate, given the reality of the COVID-19 pandemic. 


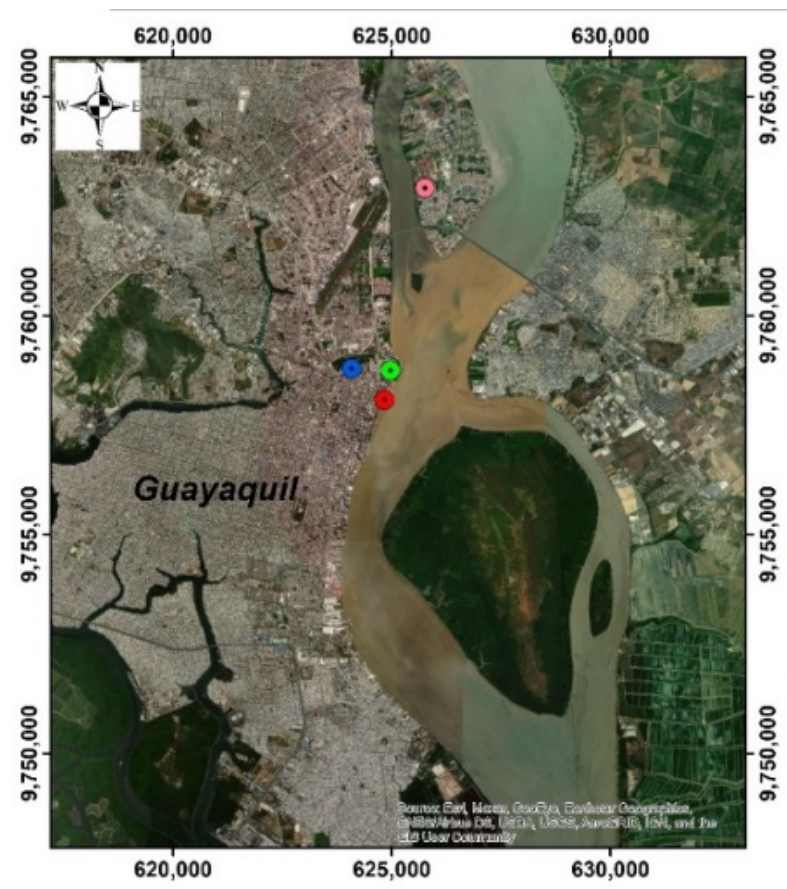

Datum: WGS84 UTM 17S

Scale: $1 \mathrm{~cm}=1 \mathrm{~km}$
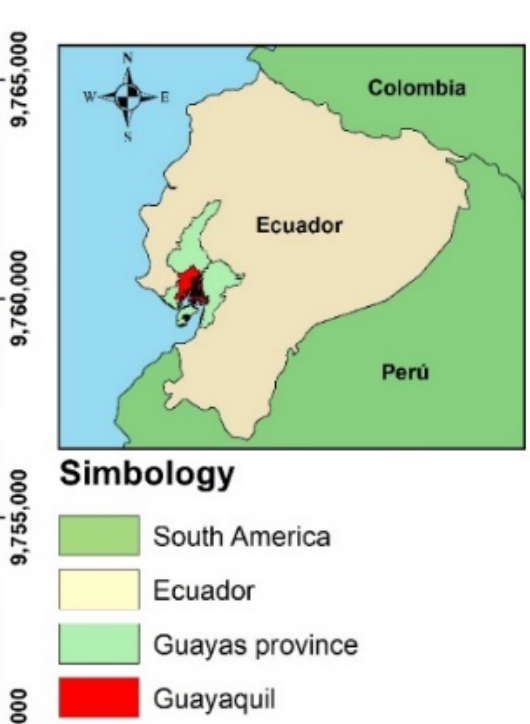

Geosites of interest

- Historical Park

- Santa Ana Hill

- Guayas river (Malecón 2000)

- Cerro del Carmen

Figure 2: The geographical location of the geosites in Guayaquil, Ecuador. (Source: Modification of [35].)

\subsection{Phase 2: Environmental assessment of geosites and analysis of their} carrying capacity for tourism

The cause-effect method is an interactive matrix implemented for environmental impact studies to represent the interactions between two components, natural and anthropogenic. This matrix is a double-entry table, where the rows are the environmental factors to be assessed, while the columns contain the value corresponding to each factor (Table 2). For this purpose, the results are analyzing with the valuation ranges in Table 1.

The calculation of the tourist carrying capacity consists of the application of three different sections, which refer to the physical carrying capacity (PCC), real carrying capacity (RCC) and effective carrying capacity (ECC) (Fig. 3). The PCC is the limit of visits that can be made to the site per day, while the RCC is a series of correction factors to the PCC that affect the site directly or indirectly, and finally, the ECC is defining as the maximum of visits that can be allowed given its management capacity [36], [37]. 
Table 1: Significance ranges.

\begin{tabular}{|c|c|c|}
\hline Range & Features & Significance \\
\hline $81-100$ & $\mathrm{E}(+)$ & $(+)$ Highly significant \\
\hline $61-80$ & $\mathrm{D}(+)$ & $(+)$ Significant \\
\hline $41-60$ & $\mathrm{C}(+)$ & $(+)$ Moderately significant \\
\hline $21-40$ & $\mathrm{~B}(+)$ & $(+)$ Insignificant \\
\hline $0-20$ & $\mathrm{~A}(+)$ & $(+)$ Not significant \\
\hline$(-) 1-20$ & $\mathrm{~A}(-)$ & $(-)$ Not significant \\
\hline$(-) 21-40$ & $\mathrm{~B}(-)$ & $(-)$ Insignificant \\
\hline$(-) 41-60$ & $\mathrm{C}(-)$ & $(-)$ Moderately significant \\
\hline$(-) 61-80$ & $\mathrm{D}(-)$ & $(-)$ Significant \\
\hline$(-) 81-100$ & $\mathrm{E}(-)$ & $(-)$ Highly significant \\
\hline
\end{tabular}

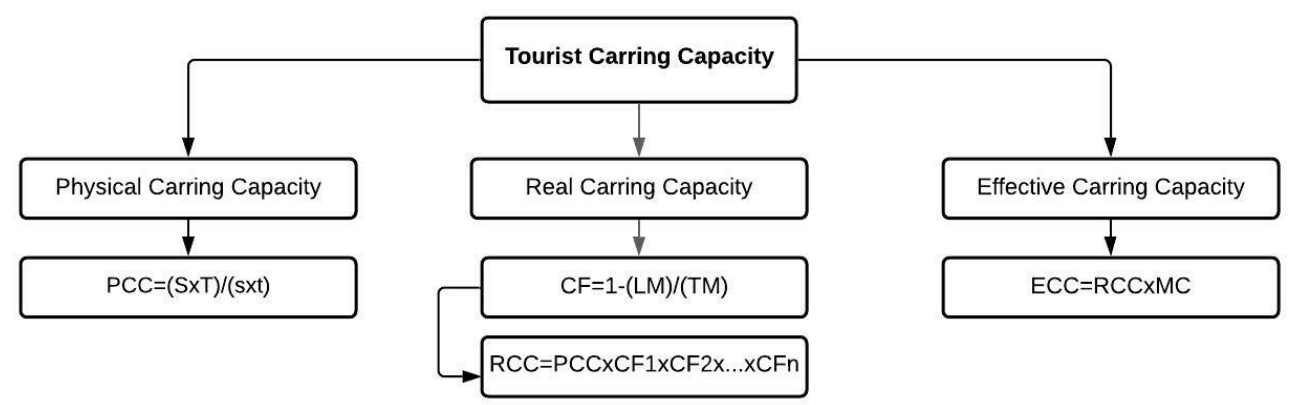

Figure 3: Main parameters analyzed for the calculation of tourist carrying capacity. $\mathrm{S}=$ Surface or total area of the geosite destined for tourists; $\mathrm{s}=$ surface per person; $\mathrm{T}=$ Time for visitors; $\mathrm{t}=$ time a person needs to visit the geosite; $\mathrm{Lm}=$ Limiting magnitude; $\mathrm{Tm}=$ Total magnitude; $\mathrm{PCC}=$ Physical carrying capacity; $\mathrm{RCC}=$ Real carrying capacity; ECC $=$ Effective carrying capacity; CF $1 \ldots \mathrm{n}=$ Correction factor of the variable $(1,2,3, \ldots, \mathrm{n}$, depending on the case); $\mathrm{MC}=$ management capacity.

\subsection{Phase 3: Interpretation of results and strategy development.}

The results allow us to analyze the status of each geosite, considering the environmental impact of tourist and human activity, and the maximum capacity to which they are limited to accommodate under COVID-19 conditions. This phase focuses on the generation of a focus group to discuss the values obtained after the evaluation of each site (Delphi method). It is an essential tool for exploring the results and determining practical actions for strategy and decision making [38].

\section{RESULTS}

The results reflect the environmental value of each geosite, determining the most relevant environmental aspects and their impact on the geosite (see Table 2). 
Table 2: Environmental assessment of four geosites of Guayaquil.

\begin{tabular}{|c|c|c|c|c|c|c|c|c|}
\hline & \multicolumn{2}{|c|}{$\begin{array}{l}\text { Historical } \\
\text { Park }\end{array}$} & \multicolumn{2}{|c|}{$\begin{array}{l}\text { Cerro del } \\
\text { Carmen }\end{array}$} & \multicolumn{2}{|c|}{$\begin{array}{l}\text { Santa Ana } \\
\text { Hill }\end{array}$} & \multicolumn{2}{|c|}{$\begin{array}{l}\text { Guayas River } \\
\text { (Malecón 2000) }\end{array}$} \\
\hline Environmental aspect & & & & & & & $\operatorname{Im}$ & ue \\
\hline Gas emissions perception & -12.5 & $\mathrm{~A}(-)$ & -32 & $\mathrm{~B}(-)$ & -32 & $\mathrm{~B}(-)$ & -24 & $\mathrm{~B}(-)$ \\
\hline Soil quality perception & 27 & $\mathrm{~B}(+)$ & 27 & $\mathrm{~B}(+)$ & 27 & $\mathrm{~B}(+)$ & 15 & $\mathrm{~A}(+)$ \\
\hline Electricity consumption & -24 & $\mathrm{~B}(-)$ & -24 & $\mathrm{~B}(-)$ & -48 & $\mathrm{C}(-)$ & -50 & $\mathrm{C}(-)$ \\
\hline Bad odors perception & -12 & $\mathrm{~A}(-)$ & -21 & $\mathrm{~B}(-)$ & -21 & $\mathrm{~B}(-)$ & -17.5 & $\mathrm{~A}(-)$ \\
\hline $\begin{array}{l}\text { Noise and vibration } \\
\text { perception }\end{array}$ & -20 & $\mathrm{~B}(-)$ & -54 & $\mathrm{C}(-)$ & -54 & $\mathrm{C}(-)$ & -40 & $\mathrm{~B}(-)$ \\
\hline $\begin{array}{l}\text { Generation or presence of } \\
\text { wastewater }\end{array}$ & -30 & $\mathrm{~B}(-)$ & -100 & $\mathrm{E}(-)$ & -100 & $\mathrm{E}(-)$ & -48 & $\mathrm{C}(-)$ \\
\hline Fauna & 56 & $\mathrm{C}(+)$ & 12 & $\mathrm{~A}(+)$ & 12 & $\mathrm{~A}(+)$ & 21 & $\mathrm{~B}(+)$ \\
\hline Flora & 54 & $\mathrm{C}(+)$ & 28 & $\mathrm{~B}(+)$ & 12 & $\mathrm{~A}(+)$ & 24 & $\mathrm{~B}(+)$ \\
\hline Ecosystem impacts & 27 & $\mathrm{~B}(+)$ & -54 & $\mathrm{C}(-)$ & -54 & $\mathrm{C}(-)$ & -24 & $\mathrm{~B}(-)$ \\
\hline $\begin{array}{l}\text { Construction for geosite } \\
\text { adjustments }\end{array}$ & 8 & $\mathrm{~A}(+)$ & -7 & $\mathrm{~A}(-)$ & -7 & $\mathrm{~A}(-)$ & -8 & $\mathrm{~A}(-)$ \\
\hline Refor & 24 & $\mathrm{~B}(+)$ & -27 & $\mathrm{~B}(-)$ & -27 & $\mathrm{~B}(-)$ & -18 & $\mathrm{~A}(-)$ \\
\hline Organic waste generation & -36 & $\mathrm{~B}(-)$ & -48 & $\mathrm{C}(-)$ & -54 & $\mathrm{C}(-)$ & -24 & $\mathrm{~B}(-)$ \\
\hline Inorganic waste generation & -16 & $\mathrm{~A}(-)$ & -54 & $\mathrm{C}(-)$ & -54 & $\mathrm{C}(-)$ & -32 & $\mathrm{~B}(-)$ \\
\hline Hazardous w: & -8 & $\mathrm{~A}(-)$ & -48 & $\mathrm{C}(-)$ & -48 & $\mathrm{C}(-)$ & -48 & $\mathrm{C}(-)$ \\
\hline Loss of vegetation cover & -7.5 & $\mathrm{~A}(-)$ & -18 & $\mathrm{~A}(-)$ & -24 & $\mathrm{~B}(-)$ & -24 & $\mathrm{~B}(-)$ \\
\hline Industrial activity & -15 & $\mathrm{~A}(-)$ & -45 & $\mathrm{C}(-)$ & -54 & $\mathrm{C}(-)$ & -72 & $\mathrm{D}(-)$ \\
\hline Comm & 48 & $\mathrm{C}(+)$ & 21 & $\mathrm{~B}(+)$ & 48 & $\mathrm{C}(+)$ & 54 & $\mathrm{C}(+)$ \\
\hline Employment generation & 42 & $\mathrm{C}(+)$ & 27 & $\mathrm{~B}(+)$ & 48 & $\mathrm{C}(+)$ & 48 & $\mathrm{C}(+)$ \\
\hline Service generation & 54 & $\mathrm{C}(+)$ & 36 & $\mathrm{~B}(+)$ & 54 & $\mathrm{C}(+)$ & 54 & $\mathrm{C}(+)$ \\
\hline $\begin{array}{l}\text { Excessive visual or } \\
\text { landscape load }\end{array}$ & 27 & $\mathrm{~B}(+)$ & 56 & $\mathrm{C}(+)$ & 72 & $\mathrm{D}($ & 56 & $\mathrm{C}(+)$ \\
\hline Social recreation & 48 & $\mathrm{C}(+)$ & 6 & $\mathrm{~A}(+)$ & 42 & $\mathrm{C}(+)$ & 56 & $\mathrm{C}(+)$ \\
\hline Physical carrying ca & 40 & $\mathrm{~B}(+)$ & 40 & $\mathrm{~B}(+)$ & 56 & $\mathrm{C}(+)$ & 72 & $\mathrm{D}(+)$ \\
\hline Tourist safety & 54 & $\mathrm{C}(+)$ & 21 & $\mathrm{~B}(+)$ & 24 & $\mathrm{~B}(+)$ & 20 & $\mathrm{~A}(+)$ \\
\hline Symbol or figure cultural & 54 & $\mathrm{C}(+)$ & 70 & $\mathrm{D}(+)$ & 90 & $\mathrm{E}(+)$ & 80 & $\mathrm{D}(+)$ \\
\hline $\begin{array}{l}\text { Presence of vehicles } \\
\text { (transport or machinery) }\end{array}$ & 35 & $\mathrm{~B}(+)$ & -63 & $\mathrm{D}(-)$ & -42 & $\mathrm{C}(-)$ & 48 & $\mathrm{C}(-)$ \\
\hline
\end{tabular}

The historic park has a negligible negative impact. The perception of gas emissions is deficient given that the park is located in an area with little intervention by vehicles, although smoke particles can founding retained in part of the vegetation, which contributes to mitigating noise pollution and transforming it into pleasant sounds. Organic waste generation and electricity consumption have a negligible impact due to the biological needs of the animals and the fact that not all the park is illuminated at night (recreational areas, restaurants, and event hall). On the other hand, the unique characteristics that make this park a vital geosite are highlighted, such as the animal shelter (where they can interact and be cared for) and the diversity of vegetation (which is cared for and reforested), positively benefiting this ecosystem. 
Given the proximity between El Cerro del Carmen and Santa Ana Hill, similar negative impacts are not very significant, such as the perception of gases from vehicles travelling in the surrounding area. Electricity consumption and the perception of noise and vibrations are other impacts caused by the presence of houses, lights, vehicles of the residents and commercial activity in the sector, in addition to nighttime activities such as bars and nightclubs. Wastewater generation is another significant factor, mainly influenced by housing and services provided by hotels and restaurants, which are also involved in solid waste and are considered a moderately significant factor. Despite the adverse effects, both geosites have significant characteristics that highlight their importance, such as the generation of jobs and services, geoforms that frame their geological activity, cultural and historical figures, and other peculiarities that make these geosites the unique cultural places in the Guayaquil city.

In the Guayas river (Malecón 2000), there are negative impacts on electricity consumption due to the installation of lights for monuments and roads, the perception of gases, noise and vibrations due to the presence of extreme games, ships/land vehicles passing around and live shows on weekends and holidays. The generation of wastewater has a moderately significant impact, given the presence of commercial establishments and other tourist activities that encourage the use of the facilities. Therefore, industrial activity is more prevalent and affects the ecosystem. However, this geosite also highlights characteristics of the city's identity, such as the generation of employment, social recreation, great tourist carrying capacity, as well as the presence of symbols, and cultural and historical figures of the Guayaquil city, which makes it one of the most visited sites by tourists and citizens.

The tourist carrying capacity of these geosites highlights the maximum number of people at each geosite, which can see in Table 3.

Table 3: Tourist carrying capacity.

\begin{tabular}{|l|c|c|c|}
\hline \multicolumn{4}{|c|}{ Results (visits per day) } \\
\hline Geosites & CCF & CCR & CCE \\
\hline Historical Park & 31,250 & 2,021 & 1,887 \\
\hline Cerro del Carmen & 113,333 & 27,036 & 21,629 \\
\hline Santa Ana Hill & 56,000 & 25,701 & 23,559 \\
\hline Guayas river (Malecón 2000) & 255,000 & 118,109 & 110,236 \\
\hline
\end{tabular}

Considering the surface in square meters for visitors and the area of each geosite, in the $\mathrm{PCC}$, it is possible to determine the maximum number of tourists that can access in a single day. However, in the RCC, there are correction factors for the previously calculated data, which significantly influences the stay and number of people on the site. Finally, the ECC presents multiple variables that refer to the capacity of each geosite to be managing most appropriately. Therefore, the geosites have a significant number of people represented by the ECC, such as the Historical Park with a maximum of 1,887 tourists, Cerro del Carmen with a permissible limit of 21,629 people, similar to Santa Ana Hill with 23,559, but the one with the most significant capacity to accommodate visitors is the Guayas River (Malecón 2000), with a capacity of up to 110,236 tourists.

\section{DISCUSSION}

From an environmental and tourism perspective, Guayaquil city has problems regarding the lack of environmental culture among its citizens and their activities that affect the environment [39]. Furthermore, contamination by the solid waste in the Guayas River 
(Malecón 2000) is another environmental problem present in this site, due to improper disposal [40], as well as the high energy consumption caused by the site's facilities, and the contamination of its banks by wastewater discharged into the river from industrial activities [41]. However, it has a tremendous socioeconomic, cultural, and recreational importance, being a geosite with great tourist/historical interest and a large tourist carrying capacity.

Despite being a tourist site that maintains its structures in better condition than the others, the Historic Park also has negative impacts from the surrounding area and slightly from within, so tour guides must receive training to inform tourists adequately [42]. On the other hand, its geographic location allows for local flora and fauna development, making it a geosite of great value for the interaction between humans and nature.

Cerro Santa Ana and Cerro del Carmen are very characteristic places of the city since they are sites with predominantly cultural and historical heritage, besides being the neighborhoods where the city of Guayaquil began [43], However, they are deteriorating due to carelessness of urban infrastructure and lack of an inhabitants culture, which has led to an increase in the crime rate [44].

Knowing the tourist carrying capacity of the four geosites is necessary to improve the sustainable use of the site. The number of people in a given geosite depends not only on the space available for their tour but also on the circumstances and factors (climatic, anthropogenic, among others), which can affect visitors' availability and interest during their visit. In addition, the physical state they present emotionally influences the tourist to see the level of management or conservation of infrastructure, equipment, and public services available to people [45].

The environmental assessment of a geosite represents an action of great importance to establish conservation strategies and an optimal environmental, social, cultural and tourism development for the site, as is the case of the National Protected Areas System of Uruguay, where three geosites are environmentally analyzing for the sustainable development of tourism [46]. With this objective and through the calculation of the carrying capacity, it intends to improve the environmental and tourism status of the geosites, allowing to know the maximum capacity of people and emerging problems in these sites receiving tourism [47]. For this, consider the site's internal characteristics, such as infrastructure, anthropogenic activities, and the natural and geological resources of the area. Therefore, keeping the status of these resources up to date is essential for the continuity of geotourism activities, thus reducing the possibility of socio-cultural deterioration and the deterioration of the sector's experience [48].

\section{CONCLUSIONS}

Four relevant geosites in Guayaquil (Historical Park, Cerro del Carmen, Santa Ana Hill, and Guayas River (Malecón 2000)) have been studied, considering environmental aspects using a cause-effect method, and the tourist carrying capacity conditioned by the effects of the COVID-19 pandemic restrictions. These calculations make for a valuation of the preservation of these geosites and visitors capacity according to health security. The strategic importance of these sites and the preponderance of geotourism as a driving force for the socio-economic aspects of Guayaquil city are demonstrating.

The cause-effect matrix allowed determining the most relevant environmental factors in the geosites within Guayaquil city. The consumption of electricity has been seen as a significant negative aspect in most geosites, being a common characteristic given the availability of these places for night events, allowing them to be part of a tourist attraction that benefits the sector socially and economically. 
The four geosites assessed are affected by the daily activities of the city (vehicular traffic, gas generation and urban noise), which are perceiving by these places and, in a few cases (Historical Park), are buffered or absorbed by the existing vegetation, which favors this type of places that are considered the lungs of the city and promote a respite for the inhabitants of their daily lives. Industrial activity is present as a negative aspect. However, in some geosites, it is the reason for jobs and services provided to the city's citizens. In addition, the inhabitants near the sites of interest benefit from the socioeconomic and tourist increase they have. Even so, they are the reason for the increase of solid waste and wastewater through housing, restaurants, hotels and other sectors that house or meet the needs of tourists.

Currently, the global COVID-19 pandemic has negatively affected tourism activity and the sectors that depended on it (restaurants, hotels and commerce in general). However, and under certain restrictions on people's capacity, geosites become an optimal socioeconomic source for the resurgence of tourism activity. This pandemic has generated significant economic loss within the tourism industry since it influences all environmental aspects, such as social distancing. However, the spread of the virus can avoid, and tourism can become a recreational activity, safe and in conditions to promote sustainable development.

\section{ACKNOWLEDGEMENTS}

This research study was possible with the valuable contribution of the "Registry of geological and mining heritage and its impact on the defence and preservation of geodiversity in Ecuador" academic research project by ESPOL University under grant nos. CIPAT-01-2018, the support of NOVA Science Research Associates and Geo-resources and Applications GIGA, ESPOL. We thank Dr. René Rodríguez of Espíritu Santo University (UEES, acronym in Spanish) for all his feedback and recommendations for this article.

\section{REFERENCES}

[1] Colville, J.F., Beale, C.M., Forest, F., Altwegg, R., Huntley, B. \& Cowling, R.M., Plant richness, turnover, and evolutionary diversity track gradients of stability and ecological opportunity in a megadiversity center. Proceedings of the National Academy of Sciences of the United States of America, 117(33), pp. 20027-20037, 2020. DOI: $10.1073 /$ pnas.1915646117.

[2] Voth, A., Los geoparques y el geoturismo: nuevos conceptos de valorización de recursos patrimoniales y desarrollo regional. XI Coloquio Ibérico de Geografía, pp. 1$15,2008$.

[3] Kozłowski, S., Geodiversity. The concept and scope of geodiversity. Przeglad Geologiczny, 52(8), pp. 833-837, 2004.

[4] Colmenero Buendía, L., Geodiversidad y Cambio Climático, University of Jaén, 2020. http://tauja.ujaen.es/handle/10953.1/12327.

[5] Kubalíková, L., Drápela, E., Kirchner, K., Bajer, A., Balková, M. \& Kuda, F., Urban geotourism development and geoconservation: Is it possible to find a balance? Environmental Science and Policy, 121, pp. 1-10, 2021.

DOI: 10.1016/j.envsci.2021.03.016.

[6] Finzi, Y., Avni, S., Maroz, A., Avriel-Avni, N., Ashckenazi-Polivoda, S. \& Ryvkin, I., Extraordinary geodiversity and geoheritage value of erosional craters of the negev craterland. Geoheritage, 11(3), pp. 875-896, 2019.

DOI: $10.1007 / \mathrm{s} 12371-018-0335-7$. 
[7] Carrión-Mero, P., Montalván-Burbano, N., Herrera-Narváez, G. \& Morante-Carballo, F., Geodiversity and mining towards the development of geotourism: A global perspective. International Journal of Design and Nature and Ecodynamics, 16(2), pp. 191-201, 2021. DOI: 10.18280/ijdne.160209.

[8] Kubalíková, L., Bajer, A. \& Balková, M., Brief notes on geodiversity and geoheritage perception by the lay public. Geosciences, 11(2), p. 54, 2021.

DOI: 10.3390/geosciences11020054.

[9] Morante-Carballo, F., Herrera-Narváez, G., Jiménez-Orellana, N. \& Carrión-Mero, P., Puyango, Ecuador petrified forest, a geological heritage of the cretaceous AlbianMiddle, and its relevance for the sustainable development of geotourism. Sustainability, 12(16), p. 6579, 2020. DOI: 10.3390/su12166579.

[10] UNESCO, Convención para la protección del patrimonio mundial cultural y natural. Conveciones y Recomendaciones, 1973, p. 170, https://unesdoc.unesco.org/ark:/ 48223/pf0000114044_spa.page $=139$.

[11] Herrera-Franco, G., Carrión-Mero, P., Aguilar-Aguilar, M., Morante-Carballo, F., Jaya-Montalvo, M. \& Morillo-Balsera, M.C., Groundwater resilience assessment in a communal coastal aquifer system. The case of Manglaralto in Santa Elena, Ecuador. Sustainability, 12(19), 2020. DOI: 10.3390/su12198290.

[12] Coombes, M.A. \& Viles, H.A., Integrating nature-based solutions and the conservation of urban built heritage: Challenges, opportunities, and prospects. Urban Forestry and Urban Greening, 63, 127192, 2021. DOI: 10.1016/j.ufug.2021.127192.

[13] Franco, G.H., Mero, P.C., Carballo, F.M., Narváez, G.H., Bitar, J.B. \& Torrens, R.B., Strategies for the development of the value of the mining-industrial heritage of the Zaruma-Portovelo, Ecuador, in the context of a geopark project. International Journal of Energy Production and Management, 5(1), pp. 48-59, 2020.

DOI: 10.2495/EQ- 5-N1-48-59.

[14] Carrión-Mero P. et al., Quantitative and qualitative assessment of the "El sexmo" tourist gold mine (Zaruma, Ecuador) as a geosite and mining site. Resources, 9(3), p. 28, 2020. DOI: 10.3390/resources9030028.

[15] Palacio Prieto, J.L., Geositios, geomorfositios y geoparques; importancia, situación actual y perspectivas en méxico. Investigaciones Geograficas, 81, p. 24, 2013. DOI: $10.14350 /$ rig.32817.

[16] Carrión-Mero, P., Morante-Carballo, F. \& Apolo-Masache, B., Evaluation of geosites as an alternative for geotouristic development in Guayaquil, Ecuador. WIT Transactions on Ecology and the Environment, vol. 241, WIT Press: Southampton and Boston, pp. 45-56, 2020. DOI: 10.2495/SDP200041.

[17] Hose, T.A., Towards a history of geotourism: Definitions, antecedents and the future. Geological Society, London, Special Publications, 300(1), pp. 37-60, 2008.

DOI: $10.1144 / \mathrm{SP} 300.5$.

[18] Herrera-Franco, G., Montalván-Burbano, N., Carrión-Mero, P., Apolo-Masache, B. \& Jaya-Montalvo, M., Research trends in geotourism: A bibliometric analysis using the scopus database. Geosciences, 10, 2020. DOI: 10.3390/geosciences10100379.

[19] Urquí, L.C. \& de la Cova, R.R.L., La geoconservación en castilla-La mancha. estado actual y perspectivas de futuro. Cuaternario y Geomorfología, 23(3), pp. 11-26, 2009.

[20] Durán Valsero, J.J., Brusi, D., Palli, L., López Martínez, J., Palacio, J. \& Vallejo, M., Geología ecológica, geodiversidad, geoconservación y patrimonio geológico: La Declaración de Girona. Comun. la IV Reun. Nac. la Com. Patrim. Geológico, pp. 6972, 1998. 
[21] Herrera-Franco, G., Alvarado-Macancela, N., Gavín-Quinchuela, T. \& Carrión-Mero, P., Participatory socio-ecological system: Manglaralto-Santa Elena, Ecuador. Geology, Ecology, and Landscapes, 2(4), pp. 303-310, 2018.

DOI: $10.1080 / 24749508.2018 .1481632$.

[22] do Nascimento, M.A.L., da Silva, M.L.N., de Almeida, M.C. \& dos Santos Costa, S.S., Evaluation of typologies, use values, degradation risk, and relevance of the Seridó aspiring UNESCO geopark geosites, northeast Brazil. Geoheritage, 13(2), p. 25, 2021. DOI: 10.1007/s12371-021-00542-2.

[23] Yan-long, Y., Fa-dong, W., Jin-fang, H., Yan-Jie, W. \& Hao, C., Spatial information management platform for Dunhuang Global Geopark. IOP Conference Series: Earth and Environmental Science, 57, 012032, 2017. DOI: 10.1088/1755-1315/012032.

[24] Herrera-Franco, G., Montalván-Burbano, N., Carrión-Mero, P., Jaya-Montalvo, M. \& Gurumendi-Noriega, M., Worldwide research on geoparks through bibliometric analysis. Sustainability, 13(3), p. 1175, 2021. DOI: 10.3390/su13031175.

[25] Mammadova, A., Integrating Japanese local government and communities into the educational curriculum on regional sustainability inside the UNESCO's biosphere reserves and geoparks. Sustainability, 13(5), p. 2497, 2021.

DOI: $10.3390 / \mathrm{su} 13052497$.

[26] Sánchez-Cortez, J.L. \& Simbaña-Tasiguano, M., Los geoparques y su implantación en América Latina. Estudios Geográficos, 79(285), p. 445, 2019.

DOI: 10.3989/estgeogr.201817.

[27] Padrón, P.S., Vásquez, C.B., Durán, S.C., Pezo, K.V., Loyola, N.A. \& Junghanns, A., Use of colored pan traps method for monitoring insect (Diptera and hymenoptera) diversity in the southern tropical Andes of Ecuador. International Journal of Tropical Insect Science, 41(1), pp. 643-652, 2021. DOI: 10.1007/s42690-020-00252-2.

[28] Velez, D. \& Romanel, C., Dynamic numerical analysis of the Mazar concrete faced rockfill Dam in Ecuador, South America, pp. 710-717, 2021.

[29] Carrión-Mero, P. et al., Assessment of geomorphosites for geotourism in the northern part of the "Ruta escondida" (Quito, Ecuador). Sustainability, 12(20), p. 8468, 2020. DOI: $10.3390 /$ su12208468.

[30] Vasallo Villalonga, Y., Rhea González, B.S. \& La Serna Gómez, A.M., La planificación y competitividad turística ecuatoriana en el contexto del geoparque imbabura. Explore Digits, 3(3), pp. 15-25, 2019.

DOI: 10.33262/exploradordigital.3i3.440.

[31] Herrera Vasquez, V.S., Composición florística de árboles y arbustos de diez parques urbanos de la ciudad de Guayaquil. Universidad de Guayaquil, 2018.

[32] Román Carrión, J.L., Puesta en valor y propuesta de quebrada Chalán, provincia de Chimborazo, como el primer parque paleontológico del Ecuador. Universidad Complutense de Madrid, Madrid, Spain, 2013.

[33] Machiels, L. et al., Zeolite mineralogy of the Cayo formation in Guayaquil, Ecuador. Applied Clay Science, 42(1), pp. 180-188, 2008. DOI: 10.1016/j.clay.2008.01.012.

[34] Machiels, L. et al., Zeolite occurrence and genesis in the Late-Cretaceous Cayo arc of coastal Ecuador: Evidence for zeolite formation in cooling marine pyroclastic flow deposits. Applied Clay Science, 87, pp. 108-119, 2014.

DOI: $10.1016 /$ j.clay.2013.10.018.

[35] IGM, Geoportal. Capas de información geográfica básica del IGM de libre acceso, Geoportal, 2013. http://www.geoportaligm.gob.ec/portal/index.php/cartografia-delibre-acceso-escala-50k/. 
[36] Cifuentes, M., Determinación de capacidad de carga turística enáreas protegidas, no. 194. Bib. Orton IICA/CATIE, 1992.

[37] Dias, I., Körössy, N. \& Selva, V.F., Determinación de la capacidad de carga turística: El caso de Playa de Tamandaré-Pernambuco-Brasil. Estudios y Perspectivas en Turismo, 21(6), pp. 1630-1645, 2012.

[38] Turner-Carrión, M. et al., A mineralogical museum as a geotourism attraction: A case study. Minerals, 11(6), 2021. DOI: 10.3390/min11060582.

[39] Barzola Morán, A.M. \& Garzón Torres, M.E., Determinación de los problemas ambientales más frecuentes de la ciudad de Guayaquil para la creación de un segmento sobre el consejo de cuidado del medio ambiente en radio onda positive. Universidad de Guayaquil, Facultad de Comunicación Social, 2012.

[40] Rocohano, J.G., Análisis comunicacional sobre el impacto de los desechos inorgánicos y su incidencia en los problemas de contaminación ambiental ciudadela las Orquídeas Guayaquil 2017. Universidad de Guayaquil, Facultad de Comunicación Social, Guayaquil, 2018.

[41] Ramos, Á. \& Maricela, E., Análisis de los conflictos socioambientales generados por la regeneración Urbana y el turismo en la planificación territorial del cerro santa ana de guayaquil. PUCE-Quito, 2019.

[42] Peña Palacios, E., Análisis de la calidad del servicio de guianza en el Parque Histórico de Guayaquil. Universidad de Guayaquil: Facultad de Comunicación Social, 2020.

[43] Gómez González, M.R. \& Yugcha Rivera, C.C., Sitios históricos de la ciudad de Guayaquil como testigo de nuestra identidad y su incidencia en el desarrollo académico en el área de estudios sociales en los estudiantes del noveno año de la Unidad de Educación Básica "Ciudad de Ibarra", zona 8, distrit. Universidad de Guayaquil. Facultad de Filosofía, Letras y Ciencias de la Educación, 2015.

[44] Montaño Hurtado, D.A., Propuesta urbano arquitectónica de un museo al aire libre en el Cerro del Carmen. Universidad de Guayaquil, 2019.

[45] Amador, E., Cayot, L., Cifuentes, M., Cruz, E., Cruz, F. \& Ayora, P., Determinación de la capacidad de carga turística en los sitios de visita del Parque Nacional Galápagos, Serv. Parq. Nac. Galápagos. Ecuador, 42 pp., 1996.

[46] Canteiro, M., Córdova-Tapia, F. \& Brazeiro, A., Tourism impact assessment: A tool to evaluate the environmental impacts of touristic activities in natural protected areas. Tourism Management Perspectives, 28, pp. 220-227, 2018.

DOI: $10.1016 /$ j.tmp.2018.09.007.

[47] Matos Márquez, L.A., del V, S. \& Colmenares, P., Revisión sobre capacidad de carga turística y la prevención de problemas ambientales en destinos emergentes (Revision on tourist carrying capacity and the prevention of environmental problems in emerging destinations). Turismo y Sociedad, 24, 2019. https://ssrn.com/abstract=3295734.

[48] Saveriades, A., Establishing the social tourism carrying capacity for the tourist resorts of the east coast of the Republic of Cyprus. Tourism Management, 21(2), pp. 147-156, 2000. DOI: 10.1016/S0261-5177(99)00044-8. 